\title{
Factors related to periodontal disease in a rural population
}

\section{Fatores associados à doença periodontal em uma população rural}

\author{
Taíze Cassia Nascimento de Macêdo* \\ Maria da Conceição N. Costa** \\ Isaac Suzart Gomes-Filho*** \\ Maria Isabel P. Vianna** \\ Carlos Teles Santos*
}

\begin{abstract}
To estimate the prevalence and related aspects of periodontitis in a rural area of the State of Bahia, Brazil, this cross-sectional study was carried out in the village of Matinha dos Pretos, Feira de Santana County, Bahia, among 172 subjects ranging from 20 to 60 years of age. During household visits, a full-mouth periodontal exam was performed on each subject, who also answered a questionnaire about socio-demographic, economic and health-related issues. The factors assessed were plaque index, bleeding on probing index, probing depth, gingival recession or hyperplasia measurements. Clinical attachment loss was also calculated. The multivariate logistic regression method was used to evaluate the relative contribution of these factors to the periodontitis condition. The prevalence of periodontitis was $24.4 \%$. The following factors were all positively associated with the presence of periodontitis: being male $(\mathrm{OR}=1.58 ; 1.00-2.53)$, being 30 years of age or older $(\mathrm{OR}=2.80 ; 1.00-7.39)$, living in a house where there was more than one person per room $(\mathrm{OR}=1.53 ; 0.96-2.45)$, being a cigarette or pipe smoker or ex-smoker $(\mathrm{OR}=1.49 ; 0.92-2.39)$, having a plaque index of over $65 \%(\mathrm{OR}=2.97 ; 2.72-7.39)$ and more than four missing teeth $(\mathrm{OR}=1.51 ; 0.82-2.78)$. The authors concluded that socioeconomic and biological factors, especially poor oral hygiene and older age, are positively associated with periodontitis in the rural population of a small village in the county of Feira de Santana, State of Bahia, Brazil.
\end{abstract}

DESCRIPTORS: Periodontitis; Prevalence; Risk factors.

RESUMO: Para estimar a prevalência e os fatores associados à periodontite em uma área rural do Estado da Bahia foi realizado um estudo transversal com 172 indivíduos, de 20 a 60 anos de idade residentes no povoado de Matinha dos Pretos, Feira de Santana (BA). Durante visitas domiciliares, um exame clínico periodontal completo foi realizado para cada indivíduo, que também respondeu a um questionário a respeito de fatores sociodemográficos, econômicos e relacionados à saúde. Foram avaliados índice de placa, índice de sangramento à sondagem, profundidade de sondagem, medidas de recessão ou hiperplasia e calculada a perda de inserção clínica. Utilizou-se análise de regressão logística multivariada para avaliar a contribuição relativa desses fatores para a periodontite. A prevalência da doença periodontal foi de $24,42 \%$. Ser homem $(O R=1,58 ; 1,00-2,53)$, ter 30 anos ou mais de idade $(\mathrm{OR}=2,80 ; 1,00-7,39)$, residir em casas com mais de uma pessoa por cômodo (OR =1,53;0,96 - 2,45), fumar ou ser ex-fumante de cigarro ou cachimbo $(O R=1,49 ; 0,92-2,39)$, ter índice de placa maior do que $65 \%(O R=2,97$; $2,72-7,39)$ e mais de quatro dentes ausentes $(\mathrm{OR}=1,51 ; 0,82-2,78)$ estiveram associados positivamente com a presença de doença. Concluiu-se que fatores socioeconômicos e biológicos, especialmente a higiene bucal inadequada e idade elevada, estão associados positivamente com a presença de periodontite na população rural de um povoado no Estado da Bahia, Brasil.

DESCRITORES: Periodontite; Prevalência; Fatores de risco.

\section{INTRODUCTION}

Periodontal disease is the most important cause of tooth loss in individuals over the age of 45 years ${ }^{15,18}$ and along with caries, is the most frequent oral health problem in the world ${ }^{4}$.

Apart from the repercussions in the oral cavity, there is evidence that this disease is associated with systemic damage ${ }^{9}$ and problems, like preterm or low birth weight in women with periodontitis $^{12,19}$.

Few epidemiological studies in the oral health area have investigated the evaluation of periodontal status. The goal of studies in the field of dentistry is mostly to study dental caries, the main cause of tooth loss in young populations. Especially in

\footnotetext{
* Master's Degree in Community Health; **PhDs in Public Health - Institute of Collective Health, Federal University of Bahia. *** PhD in Periodontics, State University of Feira de Santana.
} 
Macêdo TCN, Costa MCN, Gomes-Filho IS, Vianna MIP, Santos CT. Factors related to periodontal disease in a rural population.

Braz Oral Res 2006;20(3):257-62.

Brazil, the available information about this topic is not reliable because of the methodological limitations of the studies. Although various factors have been related to periodontitis, such as advanced age, black race, male gender, low socio-economic level, diabetes, smoking ${ }^{10,19}$, the use of medications and poor oral hygiene habits ${ }^{5}$, there is great variability in the distribution and behavior of the disease, so that different risk factors may be important at different times of the individual's life and in different population groups ${ }^{19}$.

The aim of this study was to describe the occurrence of periodontitis in a population residing in a rural area in the State of Bahia, Brazil, and to investigate the factors related to its distribution.

\section{MATERIAL AND METHODS}

A transversal study was carried out in the village of Matinha dos Pretos, State of Bahia, in the North-East region of Brazil, $14 \mathrm{~km}$ from the Feira de Santana County. In 2000 it had a population of 1,328 inhabitants, predominantly Negroes, since it originated from the confluence of fugitive slaves from an old farm, the "Fazenda Candeal"

Of the 208 individuals from 20 to 60 years of age residing in the village, 21 were excluded (pregnant women, the mentally ill, and edentulous persons) and 15 refused to participate $(8 \%)$. Thus the study population comprised 172 individuals (107 women and 65 men). By means of a questionnaire, information was obtained about the number of rooms and residents in the household, type of house, destination of garbage, electrical power availability, attention to health, smoking habits, alcoholic beverage consumption, oral hygiene habits, income, educational status, age, sex and diabetic and hypertension status.

A complete clinical periodontal exam was performed by one single examiner, the researcherdentist selected because of significant previous experience, who recorded all the variables manually with a calibrated probe. The individuals were seated on common chairs in their homes, under natural light and with the aid of a flashlight. Intra-examiner calibration was performed before the study began. The intra-examiner degree of agreement (kappa $=0.932,0.883,0.845$, and 0.819) was classified as very good for plaque index, bleeding on probing index, probing depth and clinical attachment loss, respectively, according to the classification proposed by Altman ${ }^{3}$ (1991).
Oral hygiene was assessed using the plaque index of surfaces with plaque (with basic $2 \%$ fuchsin stain) in relation to the total number of surfaces examined, thus determining the individual's plaque index ${ }^{17}$. The gingival condition was diagnosed using the bleeding on probing index ${ }^{2}$, that is, the number of bleeding sites in relation to the total number of sites examined. Sulcus/pocket probing depth ${ }^{20}$ and gingival recession or hyperplasia $^{22}$ were measured in 6 sites for each tooth, obtaining the clinical attachment loss ${ }^{22}$.

Any individual with four or more teeth presenting with one or more sites with probing depth equal to or greater than $4 \mathrm{~mm}$ and with clinical attachment loss (CAL) equal to or greater than $3 \mathrm{~mm}$ in the same place was considered to have periodontitis $^{12}$ (presence of periodontitis). When the total number of sites with probing depths greater than $3 \mathrm{~mm}$ was less than or equal to $30 \%$, the disease was classified as localized; for higher values, it was considered to be generalized ${ }^{4}$.

The disease was classified as mild (CAL of 1 to $2 \mathrm{~mm}$, taking the cementum-enamel junction as reference); moderate (CAL of 3 to $4 \mathrm{~mm}$ ); or severe $(\mathrm{CAL}>5 \mathrm{~mm})^{4}$. Descriptive analysis of the continuous variables was carried out, with the median as the cut-off point for categorization, since the majority presented with asymmetrical distribution. Disease prevalence was calculated with regard to presence, extent and severity, and association with socioeconomic and biological factors was found, using the Prevalence Ratio.

By means of Logistic Regression, the bivariate analysis was carried out between each variable in the study, and the effect in question (presence of periodontitis) and those that showed a positive association entered into a multivariate model. The populational interval was calculated from the coefficient and standard error produced by the model for each variable being analyzed, with the aim of checking the precision of the estimates obtained.

The project for this study was submitted to the Ethical Committee on Research, State University of Feira de Santana, for appreciation and was approved by it (Protocol No. 003/2004).

\section{RESULTS}

In the studied population, $37.8 \%$ were men, $51.7 \%$ were over 30 years of age, and $17.4 \%$ were hypertensive. About $51 \%$ had 4 or fewer years of (approved) schooling, 54.1\% belonged to families 
Macêdo TCN, Costa MCN, Gomes-Filho IS, Vianna MIP, Santos CT. Factors related to periodontal disease in a rural population.

Braz Oral Res 2006;20(3):257-62.

with a mean monthly per capita income equal to or less than one quarter of a minimum wage (MW), and $48.3 \%$ lived in houses with more than one person per room. It was noted that $62.2 \%$ mentioned that they had received guidance about oral health, and among those that visited the dentist $(89.5 \%), 57.6 \%$ had done so less than three years previously. However, only $52.6 \%$ received guidance about oral hygiene. Approximately 98\% of the individuals had previously consulted a medical doctor.

Cigarette and pipe smokers and ex-smokers comprised $31.4 \%$ of the study population and $9.3 \%$ consumed alcoholic beverages on a weekly basis. The majority (88.4\%) informed that they made use of a toothbrush and toothpaste twice or more times a day. The use of dental floss was related by $20.9 \%$ of individuals; of the remainder, $75 \%$ informed that they would eventually use it.

Approximately $37 \%$ of the individuals were agricultural workers, in the cattle and similar industries, $20.4 \%$ did housework, $15.1 \%$ were students, and $8.7 \%$ were service providers and the like. About 33\% lived in houses with up to 4 rooms, constructed with blocks or bricks $(76.2 \%)$, and supplied with electricity. For $81.4 \%$ of the studied population, feces and urine were disposed of in a septic tank system, $76.7 \%$ had a garbage collection service and only $32.0 \%$ had a piped water supply.

Gingivitis was observed in $97.7 \%$ of the population, corresponding to the percentage of subjects showing bleeding on probing. Periodontitis was observed in $24.4 \%$ of the population, and in $92.9 \%$ of the cases it was localized, of which $26.2 \%, 42 \%$ and $31 \%$ presented mild, moderate and severe degrees of severity, respectively. Almost $50 \%$ of the population presented with bleeding after probing in over $17 \%$ of the examined sites, and $57.6 \%$ presented with bacterial plaque in over $65 \%$ of the tooth surfaces analyzed. Fifty percent (50\%) of the population presented more than 4 missing teeth. It was noted that $52.3 \%$ had 24 or fewer teeth in good condition, excluding the remainders of roots, or teeth with unsatisfactory or badly placed restorations.

The prevalence of periodontitis increased with age $(12.4 \%$ for the age group from $20-30$ years, $46.9 \%$ and $31.3 \%$ respectively, for those from 41-50 and 51-60 years of age) and, according to Table 1, this prevalence was approximately three times higher in individuals aged 30 and over. In men, the frequency of the disease was
$35 \%$ higher. Those that had four or less years of schooling had a 1.76 times higher prevalence of periodontitis than those with more schooling. The occurrence of the disease was 1.9 times higher for those with a per capita family income equal to or less than one quarter of a minimum wage, and for the variable "agglomeration", this value was 1.74. There was no association between hypertension and periodontitis.

Furthermore, according to Table 1 , the frequency of the disease was $50 \%$ higher for those that did not receive guidance about oral health, and the association between never having been to the dentist and periodontitis was negative. Among smokers and ex-smokers, the prevalence of periodontitis was two times higher when compared to non-smokers. Frequent consumers of alcoholic beverages were shown to be attacked by the disease almost two times more often than those who did not drink regularly. Individuals with low toothbrushing frequency had 1.79 times more prevalence of periodontitis than those who brushed twice or more times a day. However, the use of dental floss was not relevant for the expression of the disease. There was strong association $(\mathrm{RP}=2.70)$ between the presence of bacterial plaque in over $65 \%$ of the tooth surfaces and the occurrence of periodontitis. Individuals that had more than four missing teeth presented with a prevalence of periodontitis 2.5 higher than the group of comparison.

For those that had 24 or fewer teeth in good condition, the frequency of the disease was 2.28 times higher than for those that had more teeth, as a function and state of satisfactory health.

Multivariate analysis (Table 2) demonstrated that there was association between age and the occurrence of periodontitis, irrespective of the other variables that entered into the model. Thus the individuals aged 30 or older had a 2.8 greater chance of presenting with periodontitis than the younger ones. Other variables that were shown to have an independent effect for the prevalence of disease are shown in Table 2.

Plaque index higher than $65 \%(\mathrm{OR}=2.97)$, being men $(\mathrm{OR}=1.58)$, residing in houses with one or more persons per room, houses with more than one person per commodore $(\mathrm{OR}=1.53)$, having over four missing teeth $(\mathrm{OR}=1.51)$ and smoking or being an ex-cigarette or pipe smoker $(O R=1.49)$. The populational interval revealed that these measures presented small variability in the population, except for the age and plaque index variables. 
Macêdo TCN, Costa MCN, Gomes-Filho IS, Vianna MIP, Santos CT. Factors related to periodontal disease in a rural population. Braz Oral Res 2006;20(3):257-62.

TABLE 1 - Prevalence and Prevalence Ratio (PR) between the socioeconomic and biological conditions, and periodontitis in the population from 20 to 60 years of age, resident in Matinha dos Pretos, Feira de Santana, State of Bahia, Brazil, 2004.

\begin{tabular}{|c|c|c|c|c|}
\hline \multicolumn{2}{|r|}{ Variables } & $\mathrm{N}^{\mathrm{o}}$ & $\begin{array}{c}\text { Prevalence } \\
(\%)\end{array}$ & PR \\
\hline \multirow{2}{*}{ 凶̃ } & Female & 107 & 21.5 & \multirow{2}{*}{1.35} \\
\hline & Male & 65 & 29.2 & \\
\hline \multirow{2}{*}{$\stackrel{\infty}{\infty}$} & $<30$ years & 83 & 12.1 & \multirow{2}{*}{2.98} \\
\hline & $\geq 30$ years & 89 & 36.0 & \\
\hline \multicolumn{5}{|c|}{ Hypertension } \\
\hline & No & 142 & 24.7 & \multirow{2}{*}{0.95} \\
\hline & Yes & 30 & 23.3 & \\
\hline \multicolumn{5}{|c|}{ Schooling } \\
\hline & $>4$ years & 85 & 17.7 & \multirow{2}{*}{1.76} \\
\hline & $\leq 4$ years & 87 & 31.0 & \\
\hline \multicolumn{5}{|c|}{ Monthly per capita family income } \\
\hline & $>1 / 4 \mathrm{MW}$ & 79 & 16.5 & \multirow{2}{*}{1.90} \\
\hline & $\leq 1 / 4 \mathrm{MW}$ & 93 & 31.2 & \\
\hline \multicolumn{5}{|c|}{ Agglomeration } \\
\hline & $\leq 1$ person $/$ room & 89 & 18.0 & \multirow{2}{*}{1.74} \\
\hline & $>1$ person/room & 83 & 31.3 & \\
\hline \multicolumn{5}{|c|}{ Guidance with regard to oral health } \\
\hline & Yes & 107 & 20.6 & \multirow{2}{*}{1.5} \\
\hline & No & 65 & 30.8 & \\
\hline \multicolumn{5}{|c|}{ Visit to the dentist } \\
\hline & Yes & 154 & 26.6 & \multirow{2}{*}{0.21} \\
\hline & No & 18 & 5.6 & \\
\hline
\end{tabular}

\begin{tabular}{l|r|c|c}
\hline \hline \multicolumn{1}{c|}{ Variables } & $\mathrm{N}^{\mathrm{o}}$ & $\begin{array}{r}\text { Prevalence } \\
(\%)\end{array}$ & $\mathrm{PR}$ \\
\hline \multicolumn{3}{|c}{ Smoker and ex-smoker } & \multicolumn{2}{|c}{} \\
\cline { 1 - 3 } No & 118 & 17.8 & \multirow{2}{*}{2.19} \\
\hline Yes & 54 & 38.9 & \\
\hline
\end{tabular}

Consumes alcoholic beverages on weekly basis

\begin{tabular}{l|r|r|r}
\hline No & 156 & 22.4 & \multirow{2}{*}{1.95} \\
\cline { 1 - 3 } Yes & 16 & 43.8 & \\
\hline
\end{tabular}

Tooth brushing frequency

\begin{tabular}{c|r|r|l}
\hline$\geq 2$ times/day & 152 & 22.4 & \multirow{2}{*}{1.79} \\
\cline { 1 - 3 } 1 time/day & 20 & 40.0 & \\
\cline { 1 - 2 } Use of dental floss & 36 & 22.2 & \multirow{2}{|l}{1.13} \\
\cline { 1 - 3 } Yes & 136 & 25.0 &
\end{tabular}

Plaque Index

\begin{tabular}{|c|c|c|c|}
\hline$\leq 65 \%$ & 73 & 12.3 & \multirow{2}{*}{2.70} \\
\hline$>65 \%$ & 99 & 33.3 & \\
\hline \multicolumn{4}{|c|}{ Number of missing teeth } \\
\hline$\leq 4$ teeth & 86 & 14.0 & \multirow{2}{*}{2.5} \\
\hline$>4$ teeth & 86 & 34.9 & \\
\hline
\end{tabular}

Number of teeth present*

\begin{tabular}{l|l|l|l}
\hline$>24$ teeth & 82 & 14.6 & \multirow{2}{*}{2.28} \\
\hline$\leq 24$ teeth & 90 & 33.3 & \\
\hline \hline
\end{tabular}

MW: Minimum wage. *Number of teeth present excluding the remainders of roots, or teeth with unsatisfactory restorations or badly placed.

\section{DISCUSSION}

Although high, the magnitude of periodontitis prevalence $(24.4 \%)$ noted in the population in the present study was not surprising, considering that it concerns adults of a very low socioeconomic level, with insufficient dental assistance, and mainly because of being resident in a rural zone, where even children present with worse oral health conditions than those in urban zones ${ }^{8}$.

This prevalence was also around 2.5 times lower than that found in a rural population in the south of Michigan/USA ${ }^{6}$. However, one cannot overlook the fact that this difference can be the result of the cut-off point of the referred study adopted for diagnosing the presence of the disease delineated as having $\geq 1$ tooth with $4 \mathrm{~mm}$ of attachment loss or $5 \mathrm{~mm}$ of pocket depth or a mean greater than $1.5 \mathrm{~mm}$ of attachment loss or $3.0 \mathrm{~mm}$ of pocket depth. Furthermore, with regard to the moderate and severe forms of the disease $(18 \%)$, the prevalence was similar to that estimated for Americans over the age of 18 years (approximately 15\%) by the American Academy of Periodontology ${ }^{9}$.

It is pointed out that the scarcity of studies on the oral health of the Brazilian population, in addition to the differences in the age groups studied and the criteria adopted for diagnosing the disease, has made it difficult to compare the results. Although a survey made in Brazil between 2002 and $2003^{14}$ encompassed urban and rural zones, the information of the latter has not yet been made available.

The observed frequency of gingivitis $(97.7 \%)$ was slightly higher than that found in the survey 
Macêdo TCN, Costa MCN, Gomes-Filho IS, Vianna MIP, Santos CT. Factors related to periodontal disease in a rural population.

Braz Oral Res 2006;20(3):257-62.

TABLE 2 - Odds Ratio (OR) estimated by means of multivariate analysis for the association between the socioeconomic and biological conditions, and Periodontitis in the population from 20 to 60 years, resident in Matinha dos Pretos, Feira de Santana, State of Bahia, Brazil, 2004.

\begin{tabular}{l|c|c}
\hline \multicolumn{1}{c|}{ Variables } & OR & $\begin{array}{c}\text { Populational } \\
\text { Interval }\end{array}$ \\
\hline Sex & 1.58 & $0.99-2.53$ \\
\hline Age & 2.80 & $1.00-7.39$ \\
\hline Schooling & 0.71 & $0.43-1.15$ \\
\hline $\begin{array}{l}\text { Monthly per capita family } \\
\text { income }\end{array}$ & 1.32 & $0.80-2.16$ \\
\hline Agglomeration & 1.53 & $0.96-2.45$ \\
\hline $\begin{array}{l}\text { Guidance with regard to } \\
\text { oral health }\end{array}$ & 1.10 & $0.72-1.67$ \\
\hline Smoker/ex-smoker & 1.49 & $0.92-2.39$ \\
\hline Use of Alcohol & 1.29 & $0.65-2.53$ \\
\hline Brushing frequency & 1.01 & $0.57-1.78$ \\
\hline Plaque Index & 2.97 & $2.72-7.39$ \\
\hline Missing teeth & 1.51 & $0.82-2.78$ \\
\hline Teeth present & 1.01 & $0.57-1.79$ \\
\hline \hline
\end{tabular}

carried out in Brazil (94.6\%) in 1986, restricted to the urban population ${ }^{13}$, which is consistent with the fact that in the developing countries, gingivitis associated with plaque deposits and calculus is common among adults ${ }^{20}$. Such findings reflect the population's neediness with regard to simple oral health care, since the inflammatory response set of by bacterial plaque on the teeth could disappear when it is removed.

The high plaque index found is conflicting with the high proportion of interviewees who informed that they brushed their teeth two or more times a day, bearing in mind that brushing and the use of dental floss are considered to be the most efficient methods of plaque removal ${ }^{1}$. It is possible that in the study population the practice of toothbrushing is inefficient or less frequent than was related. Frequently, the knowledge of the ideal frequency of tooth brushing does not result in real changes in the individuals' behavior, due to the socioeconomic and cultural peculiarities of each community.

The population's neediness with regard to oral health attendance was evident from the large proportion of individuals with tooth losses and the reduced frequency of those with teeth in good health and functional conditions, and it is consistent with the records in Brazil of high percentages of tooth losses in individuals in the age group from 35-44 and 65 years of age, in which the proportion of periodontally healthy persons was practically null ${ }^{7}$. This reality is reflected in the strong association found between bacterial plaque and periodontitis in these individuals.

In spite of this study covering a relatively homogeneous rural population, as far as socioeconomic level is concerned, the finding of an association between "agglomeration" and periodontitis might be an indication that this disease is related to socioeconomic factors. On the other hand, the association between age and periodontitis should be considered less important than oral hygiene, as confirmed by other studies ${ }^{11}$. However, it might have been possible to make a better evaluation of the effect of the age variable, if there had been a population of a size that allowed it to be distributed into smaller age group intervals than was possible in the present study. Considering that the whole adult population was studied, the Odds Ratio should be analyzed as an absolute value, being the $95 \%$ confidence interval a measure of variability and not of statistical inference.

Greater occurrence of the disease was found among men, but in general, the findings in the literature in this connection are controversial, and they are attributed to differences in oral hygiene and the behavior of visiting the dentist ${ }^{21}$, which was not observed in Matinha. As far as the smoking habit is concerned - the main risk factor for periodontitis in men ${ }^{10}$ - perhaps its effect was attenuated in the present study, due to the fact that many people smoked pipes and not conventional cigarettes, as extensively referred to in researches.

The association observed between the number of missing teeth and periodontitis reinforces the hypothesis that some individuals may not have been classified as sick or may even have been fitted into a classification of milder extent and severity, as they had already lost their teeth due to periodontitis at a more advanced stage, leading to a bias of selective survival and, consequently to a bias of classification. Furthermore, the clinical exam did not proceed under ideal conditions, apart from the replies to the questionnaire being subject to manipulation by the interviewee. Even so, it is believed that accurate clinical descriptors were obtained with the use of probes marked with 1 and $2 \mathrm{~mm}$, as opposed to the WHO probes used in the epidemiological studies in Brazil. The small number of risk factors explored and the restricted 
population, which makes it impossible to generalize its results to the general population, are other limitations of the present study. However, special care was taken while diagnosing periodontitis with regard to its presence, extent and severity with the purpose of not underestimating its prevalence, a fact observed in the majority of studies that used indexes of doubtful validity for identifying the disease that have, therefore, been discarded ${ }^{20}$.

\section{REFERENCES}

1. Abegg C. Hábitos de higiene bucal de adultos porto-alegrenses. Rev Saúde Pública 1997;31(6):586-93.

2. Ainamo J, Bay I. Problems and proposals for recording gingivitis and plaque. J Clin Periodontol 1975;25(4):22935.

3. Altman DG. Practical Statistics for Medical Research. New York: Chapman and Hall; 1991.

4. Armitage GC. Development of a classification system for periodontal diseases and conditions. Ann Periodontol 1999;4(1):1-6.

5. Axelsson P, Lindhe J, Nyström B. On the prevention of caries and periodontal disease. Results of a 15-year longitudinal study in adults. J Clin Periodontol 1991;18:182-9.

6. Bagramian RA, Farghaly MM, Lopatin D, Soweers M, Sued $\mathrm{S}$, Pomerville JL. A comparison of periodontal disease among rural Amish and non-Amish adults. J Clin Periodontol 1994;21:386-90.

7. Cangussu MCT, Coelho EO, Castellanos Fernandes RA. Condições de saúde bucal em adultos e idosos em Itatiba/ SP, Brasil - 2000. Rev Odontol UNESP 2001a;30(2):24556.

8. Cangussu MCT, Coelho EO, Castellanos Fernandes RA. Epidemiologia e iniqüidade em saúde bucal aos 5, 12 e 15 anos de idade no município de Itatiba/SP, 2000. Rev Fac Odontol Bauru 2001b;9(1/2):77-85.

9. Consensus Report. Periodontal diseases: epidemiology and diagnosis. Ann of Periodontol 1996 Nov; 1(1):216-22.

10. Genco RJ. Current view of risk factors for periodontal diseases. J Periodontol 1996;67:1041-9.

11. Lang NP, Mombelli AM, Attström R. Placa e cálculo dentais. In: Lindhe J. Tratado de Periodontologia Clínica e Implantodontia Oral. $3^{a}$ ed. Tradução por Edson Jorge Lima Moreira. Rio de Janeiro: Guanabara Koogan; 1999. p. 66-89.

12. Lopez NJ, Smith PC, Gutierrez J. Periodontal therapy may reduce the risk of preterm low birth weight in women

\section{CONCLUSIONS}

The high prevalence of periodontitis associated to biological and socioeconomic factors noted in the population of the present study reflects population restraints regarding individual hygiene and oral health. The necessity of redefining public health policy in order to consider integrating the dental professional into health teams was thus identified.

with periodontal disease: a randomized controlled trial. J Periodontol 2002;73:911-24.

13. Ministério da Saúde. Levantamento epidemiológico em saúde bucal - Brasil, zona urbana, 1986. Brasília: Centro de Documentação do Ministério da Saúde; 1988.

14. Ministério da Saúde. Projeto SB 2000: Condições de saúde bucal da população brasileira 2002-2003 - Resultados principais. Brasília: Centro de Documentação do Ministério da Saúde; 2004.

15. Narvai PC. O Brasil e as metas OMS-2000 [online]

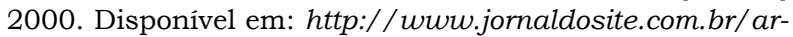
quivo/anteriores/capel/capel5.htm.

16. Nascimento MAA. As práticas populares de cura no povoado de Matinha dos Pretos - BA: Eliminar, reduzir ou convalidar? [Tese de Doutorado]. Ribeirão Preto: Universidade de São Paulo; 1997.

17. O'Leary TJ, Drake RB, Naylor JE. The plaque control record. J Periodontol 1972;43(1):38-9.

18. Oppermann RV, Gomes SC. Periodontia em Saúde Pública. In: Tunes VR, Rapp GE. Atualização em periodontia e implantodontia. São Paulo: Artes Médicas; 1999. p. 19-28.

19. Papapanou PN, Lindhe J. Epidemiologia da doença periodontal. In: Lindhe J. Tratado de Periodontologia Clínica e Implantodontia Oral. $3^{a}$ ed. Tradução por Edson Jorge Lima Moreira. Rio de Janeiro: Guanabara Koogan; 1999. p. 43-62.

20. Pihlstrom BL, Ortiz-Campos C, McHugh RB. A randomized four-year study of periodontal therapy. J Clin Periodontol 1981;52:524-41.

21. Position Paper. Epidemiology of periodontal diseases. J Periodontol 1996;67(9):935-45.

22. Ramfjord SP. Index for prevalence and index of periodontal disease. J Periodontol 1959;30:51-9.

Received for publication on Jul 14, 2005

Sent for alterations on Oct 21, 2005

Accepted for publication on May 15, 2006 